\title{
DETERMINASI LINGKUNGAN KERJA DAN KOMITMEN ORGANISASI TERHADAP KINERJA KARYAWAN PT. SINAR NIAGA SEJAHTERA SIDOARJO
}

\author{
Putri Amalia Rulysca \\ Universitas Negeri Surabaya \\ putrirulysca@mhs.unesa.ac.id
}

Abstract

\begin{abstract}
Improved employee performance will give an impact on the progress positively of every organization to survive in an unstable business environment competition. PT. Sinar Niaga Sejahtera Sidoarjo has few problems surrounding the work environment and organizational commitment that is feared to give an effect on the performance of its employees. This quantitative study was conducted on 100 employees of PT. Sinar Niaga Sejahtera Sidoarjo in 2019. Multiple linear regression was used to analyze all data among the study. To make certain about the result of the environment of work and commitment of organization on the performance of employees at PT. Sinar Niaga Sejahtera Sidoarjo was the principal intention of this study. As an outcome, the environment of work and commitment of organization shows a significant positive effect on the performance of employees, partially and simultaneously. It is recommended that management needs to maintain a conducive environment of work nowadays and commitment of organization that has been a stick in the employees. Also, things that need to be improved are providing a canteen or break room for employees, motivating employees with an individual approach or by giving equal rewards for their work which are making the small possibility of them leaving the organization and doing more detailed supervision of the work processes of their employees that will make them less likely to act outside procedure and not following orders from management. Instead, further research can add responses from other variables, such as compensation and employee motivation.
\end{abstract}

Keywords: commitment; performance; work environment.

\section{PENDAHULUAN}

Kinerja para karyawan bila ditingkatkan, akan membawa dampak positif atas kemajuan organisasi untuk mempertahankan usahanya dalam kondisi ketidakstabilan persaingan lingkungan bisnis yang terjadi. Maka dari itu, berbagai upaya untuk meningkatkan kinerja para karyawan merupakan isu paling serius bagi manajemen organisasi, karena berhasil atau tidaknya pencapaian target dan keberlangsungan hidup organisasi bergantung pada hasil atau kualitas kinerja karyawannya (Sari, 2015).

Kinerja karyawan memiliki banyak faktor penentu yang memengaruhinya. Menurut Triwibowo \& Zamora (2016) menyatakan hasil kerja/kinerja karyawan ditentukan oleh keadaan di mana terbentuk lingkungan/suasana kerja positif yang mendukung efisiensi serta efektivitas kerjanya. Jain dan Kaur dalam Pitaloka \& Sofia (2014) menyatakan lingkungan kerja mencakup seluruh aspek yang menunjukkan aksi dan reaksi dari tubuh dan pikiran seorang karyawan. Apabila lingkungan kerja menyenangkan maka tingkat kelelahan, kebosanan dan kejenuhan dapat ditekan dan kualitas kerja akan dapat dimaksimalkan. Lingkungan dalam pekerjaan merupakan suatu konsep yang luas, karena mencakup aspek-aspek fisik, psikologi dan kondisi sosial dalam pekerjaan. Lingkungan kerja merupakan segala hal yang ada di luar organisasi yang secara potensial memengaruhi kinerja karyawan dan akhirnya memengaruhi kinerja organisasi (Robbins dalam Widodo, 2014). Hasil tersebut sesuai dengan hasil penelitian Maryanto (2016) yang menjelaskan lingkungan kerja berpengaruh positif terhadap kinerja karyawan.

Selain faktor lingkungan dalam pekerjaan, komitmen para pekerja/ karyawan dalam organisasi juga turut berkontribusi besar pada hasil/ kinerja para karyawan. Setiap institusi tentu mempunyai tujuan utama yaitu untuk mencapai laba atau keuntungan. Tujuan itu tentu juga akan tercapai jika karyawan mempunyai rasa komitmen yang besar pada organisasi. Jika para pekerja/ karyawan telah mempunyai rasa komitmen yang baik pada organisasinya, maka mereka akan senantiasa memperjuangkan tujuan organisasi secara maksimal (Triwibowo \& Zamora, 2016). Hakim (2015) menyatakan bahwa 
Putri Amalia Rulysca. Determinasi Lingkungan Kerja dan Komitmen Organisasi terhadap Kinerja Karyawan PT. Sinar Niaga Sejahtera Sidoarjo

karyawan yang memiliki komitmen organisasional akan terus bertahan dan turut terlibat dalam upaya untuk memperjuangkan visi, misi, serta tujuan dari organisasinya sehingga setiap organisasi dapat berharap untuk mencapai keunggulan bersaingan melalui dukungan komitmen karyawan terhadap organisasinya. Jonathan et al. (2013) menyatakan bahwa komitmen organisasi merupakan bagian yang penting dalam organisasi yang menjadi penopang pencapaian tujuan organisasi. Selaras dengan temuan Triwibowo \& Zamora (2016) yang menjelaskan komitmen organisasional berdampak secara signifikan terhadap adanya kinerja/hasil kerja karyawan.

Kinerja diperoleh dan sesuai harapan institusi/ organisasi akan ditunjukkan oleh para pekerja/karyawan jika dimulai dari terciptanya lingkungan yang kondusif dalam pekerjaan dan komitmen bekerja yang besar (Farantoro \& Nasution, 2013; Triwibowo \& Zamora, 2016). Untuk membuktikan anggapan itu, maka dilakukan studi dengan tujuan untuk mengetahui pengaruh lingkungan kerja terhadap kinerja karyawan, pengaruh komitmen organisasi terhadap kinerja karyawan, serta untuk mengetahui pengaruh lingkungan kerja dan komitmen organisasi terhadap kinerja karyawan PT. Sinar Niaga Sejahtera.

\section{KAJIAN PUSTAKA DAN PENGEMBANGAN HIPOTESIS}

\section{Lingkungan Kerja}

Baraba (2013) menyatakan bahwa lingkungan kerja merupakan segala sesuatu yang ada di sekitar karyawan yang dapat memengaruhi dirinya dalam upaya menjalankan dan menyelesaikan tugas-tugas yang diberikan kepadanya dari suatu organisasi. Lingkungan kerja merupakan segala sesuatu yang ada di sekitar pekerja dan yang dapat memengaruhi dirinya dalam menjalankan tugas yang dibebankan (Dewi, 2015). Lingkungan kerja adalah segala sesuatu yang ada di sekitar para pekerja dan yang dapat memengaruhi dirinya dalam menjalankan tugas yang dibebankan (Abidin et al., 2016).

Lingkungan kerja memiliki beberapa indikator yaitu dapat meliputi lingkungan kerja fisik maupun nonfisik (Samson et al., 2015). Hal ini seperti yang dikemukakan oleh Farantoro \& Nasution (2013) yang menyatakan bahwa indikator dari lingkungan kerja meliputi lingkungan kerja fisikyang terdiri dari bangunan tempat bekerja, ruang kerja, ventilasi, tempat istirahat, tempat ibadah, sarana angkutan, dan lingkungan kerja nonfisik yaitu hubungan yang terjalin di antara karyawan.

\section{Komitmen Organisasi}

Komitmen organisasi adalah suatu konstruk psikologis yang merupakan karakterisitik hubungan anggota organisasi dengan organisasinya dan memiliki implikasi terhadap keputusan individu untuk melanjutkan keanggotaannya dalam berorganisasi (Zurnali dalam Aprillia, 2015). Menurut Handaru et al. (2013) mengatakan bahwa komitmen dipandang sebagai orientasi nilai terhadap organisasi yang menunjukkan individu sangat memikirkan dan mengutamakan pekerjaan dan organisasinya. Dharmanegara et al. (2016) menyatakan komitmen organisasi mendorong karyawan untuk menunjukkan perilaku yang positif, seperti disiplin kerja, mematuhi kebijakan dan peraturan organisasi, membangun hubungan yang baik dengan rekan kerja, serta meningkatkan pencapaian dalam pekerjaan. Maka dari itu, dapat dijelaskan bahwa komitmen berorganisasi merupakan kesetiaan para pekerja/ karyawan kepada institusi/organisasi dan keinginan dari karyawan itu untuk memaksimalkan pencapaian tujuan organisasi.

Penelitian ini dilakukan menggunakan indikator-indikator yang merujuk pada penelitian Farantoro \& Nasution (2013) yang menyebutkan indikator dari komitmen karyawan terhadap organisasi meliputi keterikatan emosional, keterlibatan dalam organisasi, sedikit pilihan, resiko pekerjaan, kesetiaan, dan kebanggaan.

\section{Kinerja Karyawan}

Kinerja merupakan kegiatan atau aktivitas yang dilakukan oleh individu yang bertujuan untuk mencapai target yang telah ditetapkan (Nazwirman, 2019). Menurut Ahmad et al. (2014), kinerja karyawan merupakan hasil kerja dari segi kuantitas yang mampu diselesaikan sesuai dengan target yang ditentukan. Sementara itu, menurut Qatmeemalmarhoon et al. (2017), kinerja diartikan sebagai 
hasil kerja yang dicapai secara kuantitas oleh seorang individu (pekerja/ karyawan) berdasarkan tanggung jawab yang dibebankan institusi/organisasi dalam pelaksanaan tugasnya, serta tugas tersebut diselesaikan sesuai dengan target dari organisasinya. Pada dasarnya, kinerja didefinisikan sebagai pencapaian prestasi atau hasil kerja seseorang. Lebih dari itu, kinerja adalah akhir dari pekerjaan dan kegiatan yang dilakukan oleh seseorang sebagai upaya tercapainya suatu target/ tujuan.

Kinerja karyawan memiliki beberapa indikator menurut Maryanto (2016) yang terdiri dari jumlah pekerjaan, mutu pekerjaan, penggunaan waktu, jumlah kehadiran, dan korporasi/kerjasama. Sementara itu, menurut Rivai \& Basri (2005) menyebutkan indikator kinerja karyawan terdiri dari kualitas kerja, kuantitas kerja, tanggung jawab, dan sikap. Mengacu pada indikator dari dua teori tersebut, maka penelitian ini menggunakan indikator-indikator kinerja karyawan yang terdiri dari kualitas kerja, kuantitas kerja, tanggung jawab, dan sikap.

\section{Lingkungan Kerja terhadap Kinerja Karyawan}

Lingkungan dalam pekerjaan merujuk pada keadaan yang ditemui di wilayah kerja para pekerja/ karyawan yang bisa memengaruhinya dalam melaksanakan pekerjaan dari organisasi yang menjadi tanggung jawabnya. Keadaan tersebut meliputi kondisi bangunan atau gedung tempat bekerja, kondisi ruang kerja karyawan, serta keharmonisan hubungan antar pekerja/ karyawan. Setiap karyawan yang bekerja dan dengan didukung oleh lingkungan pekerjaan yang kondusif tentu akan mempermudahnya dalam penyelesaian pekerjaan dan tanggung jawab yang dilimpahkan oleh organisasi dengan baik pula atau dapat dikatakan karyawan akan memiliki kinerja yang baik (Maryanto, 2016; Triwibowo \& Zamora, 2016).

\section{Hubungan antar Variabel}

Komitmen organisasional menunjukkan kesetiaan pekerja/ karyawan kepada institusi/ organisasi dan keinginan pekerja/ karyawan untuk memaksimalkan tujuan organisasi. Komitmen organisasional oleh para pekerja/ karyawan ini berarti bahwa karyawan memiliki sikap dan perilaku yang menunjukkan perasaan senang atau tidak senang pada institusi/ organisasi. Hal itu tercermin dalam ikatan emosinya terhadap organisasi, keterlibatannya dalam aktivitas organisasi, kesetiaannya terhadap organisasi meski ia menyadari pekerjaan yang ia lakukan sangat beresiko, serta rasa bangga karena menjadi salah satu bagian dari organisasinya. Karyawan dengan komitmen tinggi tentu akan berusaha keras menunjukkan kinerja yang baik dalam melaksanakan pekerjaan dan tanggung jawabnya semata-mata demi mencapai tujuan organisasi (Farantoro \& Nasution, 2013; Hakim, 2015; Maryanto, 2016).

H1: Lingkungan kerja berpengaruh terhadap kinerja karyawan.

H2: Komitmen organisasi berpengaruh terhadap kinerja karyawan.

H3: Lingkungan kerja dan komitmen organisasi secara simultan berpengaruh terhadap kinerja karyawan.

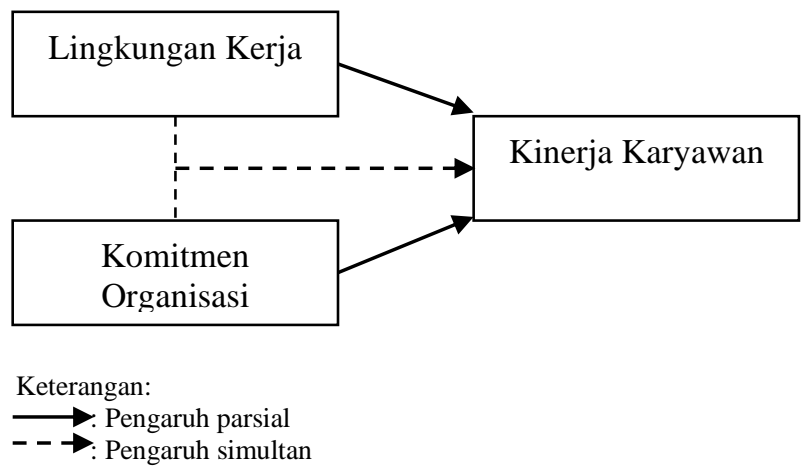

Gambar 1. KERANGKA BERPIKIR 
Putri Amalia Rulysca. Determinasi Lingkungan Kerja dan Komitmen Organisasi terhadap Kinerja Karyawan PT. Sinar Niaga Sejahtera Sidoarjo

\section{METODE PENELITIAN}

Studi ini adalah kuantitatif dan menggunakan rancangan korelasional. Penelitian ini menguji determinasi lingkungan kerja dan komitmen organisasi terhadap kinerja karyawan PT. Sinar Niaga Sejahtera Sidoarjo. Jumlah populasi dan sampel penelitian berjumlah 100 karyawan bagian kantor dan lapangan. Teknik sampling jenuh digunakan dalam pengambilan sampel.

Variabel bebas atau independen yaitu lingkungan kerja dan komitmen organisasi. Variabel terikat atau dependen yaitu kinerja karyawan. Instrumen atau alat penelitian yang digunakan adalah angket atau kuesioner yang berisi beberapa pernyataan yang tertulis sebanyak 34 butir untuk menghasilkan respon sebagai data perolehan informasi. Skor pengukuran dalam angket menggunakan skala likert 1 hingga 5 dengan kategori sangat tidak setuju (STS), tidak setuju (TS), cukup setuju (C), setuju (S) dan sangat setuju (SS). Teknik pengumpulan data menggunakan kuesioner, wawancara dan observasi. Teknik regresi linier berganda dengan aplikasi SPSS 18.0 for Windows digunakan untuk menganalisis studi yang dilakukan.

\section{HASIL DAN PEMBAHASAN}

\section{Karakteristik Responden}

Karakteristik yang diperoleh berdasarkan jenis kelamin responden perempuan lebih sedikit dibandingkan dengan jumlah responden laki-laki, di mana prosentase responden laki-laki sebesar $81 \%$, sedangkan prosentase responden perempuan hanya $19 \%$. Hal tersebut dapat diidentifikasi bahwa PT. Sinar Niaga Sejahtera Sidoarjo yang bergerak di bidang distribusi memerlukan tenaga kerja yang cenderung terlibat dengan kerja lapangan/di luar kantor.

Berdasarkan karakteristik berdasarkan usia dapat diketahui jumlah responden karyawan PT. Sinar Niaga Sejahtera Sidoarjo yang paling banyak adalah yang berusia $>30$ s/d 40 tahun sebanyak 39 responden atau 39\%. Responden karyawan PT. Sinar Niaga Sejahtera Sidoarjo yang berusia $>18 \mathrm{~s} / \mathrm{d}$ 30 tahun sebanyak 32 responden atau $32 \%$. Kemudian, responden karyawan PT. Sinar Niaga Sejahtera Sidoarjo yang berusia $>40 \mathrm{~s} / \mathrm{d} 50$ tahun sebanyak 18 responden atau $18 \%$. Terakhir, yang paling sedikit adalah responden karyawan PT. Sinar Niaga Sejahtera Sidoarjo yang berusia $>50$ tahun sebanyak 11 responden atau $11 \%$. Hasil tersebut menunjukkan bahwa usia produktif sebagai karyawan di PT. Sinar Niaga Sejahtera Sidoarjo adalah antara 30 hingga 40 tahun.

Berdasarkan karakteristik berdasarkan pendidikan dapat diketahui jumlah responden PT. Sinar Niaga Sejahtera Sidoarjo yang paling banyak adalah berpendidikan strata 1 (S1) sebanyak 58 responden atau 58\%. Responden PT. Sinar Niaga Sejahtera Sidoarjo yang berpendidikan sekolah menengah atas (SMA/ sederajat) sebanyak 27 responden atau 27\%. Kemudian, responden PT. Sinar Niaga Sejahtera Sidoarjo yang berpendidikan diploma 3 (D3) sebanyak 8 responden atau 8\%. Terakhir, yang paling sedikit adalah responden PT. Sinar Niaga Sejahtera Sidoarjo yang berpendidikan strata 2 (S2) sebanyak 7 responden atau 7\%. Hasil tersebut menunjukkan bahwa dimungkinkan karyawan dengan lulusan pendidikan S1 memiliki tingkat kemampuan analisis yang baik dan lebih banyak kesempatan untuk berkarir.

Berdasarkan karakteristik berdasarkan masa kerja dapat diketahui jumlah responden PT. Sinar Niaga Sejahtera Sidoarjo yang paling besar adalah pada masa kerja $0 \mathrm{~s} / \mathrm{d} 5$ tahun sejumlah 36 responden atau 36\%. Responden PT. Sinar Niaga Sejahtera Sidoarjo dengan masa kerja lebih dari 5 s/d 10 tahun sejumlah 29 responden atau 29\%. Kemudian, responden PT. Sinar Niaga Sejahtera Sidoarjo dengan masa kerja lebih dari $10 \mathrm{~s} / \mathrm{d} 15$ tahun sejumlah 21 responden atau 21\%. Terakhir, yang paling sedikit adalah responden PT. Sinar Niaga Sejahtera Sidoarjo dengan masa kerja $>15$ tahun sebanyak 14 responden atau $14 \%$. Hasil tersebut menunjukkan bahwa dimungkinkan seringnya terjadi karyawan yang keluar masuk kerja di PT. Sinar Niaga Sejahtera Sidoarjo. 


\section{Uji Validitas}

Hasil uji validitas yang diuji menggunakan analisis corrected item-total correlation dengan program SPSS for windows menghasilkan nilai koefisien tingkat validitas dari masing-masing item yang digunakan cukup bagus. Hasil uji validitas adalah perbandingan $r_{\text {hitung }}$ dengan $r_{\text {tabel }}$ dengan signifikansi $5 \%$, jika nilai $r_{\text {hitung }} \geq \mathrm{r}_{\text {tabel }}$, maka item yang disajikan valid (Yamin \& Kurniawan, 2014). $\mathrm{r}_{\text {hitung }}$ memiliki skor lebih tinggi daripada $r_{\text {tabel }}$ yakni 0.197. Maka dari itu, seluruh item pernyataan pada instrumen lingkungan kerja, komitmen organisasi dan kinerja karyawan diartikan valid.

Tabel 1.

\section{RINGKASAN HASIL UJI VALIDITAS INSTRUMEN}

\begin{tabular}{lrlrrrrrr}
\hline Item & $\begin{array}{c}\text { Corrected } \\
\text { Item-Total } \\
\text { Correlation }\end{array}$ & Ket. & Item & $\begin{array}{r}\text { Corrected } \\
\text { Item-Total } \\
\text { Correlation }\end{array}$ & Ket. & Item & $\begin{array}{r}\text { Corrected } \\
\text { Item-Total } \\
\text { Correlation }\end{array}$ & Ket. \\
\hline X1.1 & .221 & Valid & X2.15 & .503 & Valid & Y27 & .587 & Valid \\
X1.2 & .300 & Valid & X2.16 & .626 & Valid & Y28 & .704 & Valid \\
X1.3 & .219 & Valid & X2.17 & .591 & Valid & Y29 & .735 & Valid \\
X1.4 & .211 & Valid & X2.18 & .637 & Valid & Y30 & .808 & Valid \\
X1.5 & .215 & Valid & X2.19 & .745 & Valid & Y31 & .741 & Valid \\
X1.6 & .240 & Valid & X2.20 & .674 & Valid & Y32 & .867 & Valid \\
X1.7 & .337 & Valid & X2.21 & .517 & Valid & Y33 & .701 & Valid \\
X1.8 & .640 & Valid & X2.22 & .746 & Valid & Y34 & .803 & Valid \\
X1.9 & .543 & Valid & X2.23 & .665 & Valid & & & \\
X1.10 & .337 & Valid & X2.24 & .475 & Valid & & & \\
X1.11 & .676 & Valid & X2.25 & .729 & Valid & & & \\
X1.12 & .657 & Valid & X2.26 & .695 & Valid & & & \\
X1.13 & .551 & Valid & & & & & & \\
X1.14 & .387 & Valid & & & & & & \\
\hline S14 & .387 & & & & & & & \\
\hline
\end{tabular}

Sumber: Data diolah (2020)

\section{Uji Reliabilitas}

Cara memutuskan reliabilitasnya menggunakan batasan 0,6, dengan kriteria yaitu reliabilitas < 0,6 berarti kurang baik, reliabilitas 0,7 dapat diterima, reliabilitas $>0,8$ berarti baik (Yamin \& Kurniawan, 2014). Adapun hasilnya adalah lingkungan kerja memiliki nilai cronbach alpha sebesar 0,784, komitmen organisasi memiliki nilai cronbach alpha sebesar 0,903, dan kinerja karyawan memiliki nilai cronbach alpha sebesar 0,922. Variabel lingkungan kerja tergolong dalam kriteria reliabilitas 0,7 yang berarti dapat diterima, variabel komitmen organisasi tergolong dalam kriteria reliabilitas $>0,8$ yang berarti baik dan variabel kinerja karyawan tergolong dalam kriteria reliabilitas $>0,8$ yang berarti baik pula (Yamin \& Kurniawan, 2014). Sehingga, dapat diartikan bahwa seluruh item dalam instrumen dinyatakan reliabel.

\section{Uji Normalitas}

Berdasarkan hasil uji normalitas menunjukkan bahwa distribusi data telah terdistribusi secara normal, digambarkan dengan titik-titik atau penyebaran data berada di sekitar garis diagonal dan berjalan di arah garis diagonal, sehingga asumsi normalitas telah terpenuhi pada model regresi yang ada seperti yang dapat dilihat di Gambar 2.

\section{Uji Heteroskedastisitas}

Berdasarkan hasil uji heteroskedastisitas menunjukkan titik-titik yang tersebar baik di atas maupun di bawah angka 0 pada sumbu Y dan secara acak tidak menggambarkan pola tertentu (Priyatno, 2010). Sehingga model regresi yang ada telah memenuhi asumsi heteroskedastisitas seperti yang dapat dilihat di Gambar 3.

\section{Uji Multikolinearitas}

Hasil uji multikolinearitas memperoleh nilai tolerance setiap variabel lebih dari 0,1 yang mana lingkungan kerja dan komitmen organisasi bernilai 0,542. Angka VIF pada setiap variabel yaitu 
Putri Amalia Rulysca. Determinasi Lingkungan Kerja dan Komitmen Organisasi terhadap Kinerja Karyawan PT. Sinar Niaga Sejahtera Sidoarjo

variabel lingkungan kerja dan komitmen organisasi memiliki angka sebesar 1,844 yang mana angka VIF lebih kecil dari 10 (Priyatno, 2010). Maka dari itu, dalam model regresi tidak terjadi hubungan antar variabel bebas atau independen dan asumsi multikolinearitas telah terpenuhi.

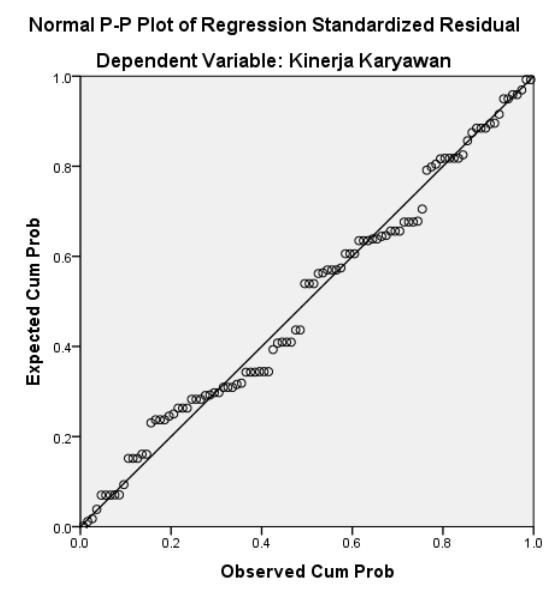

Sumber: Hasil olah data (2020)

\section{Gambar 2. HASIL UJI NORMALITAS}

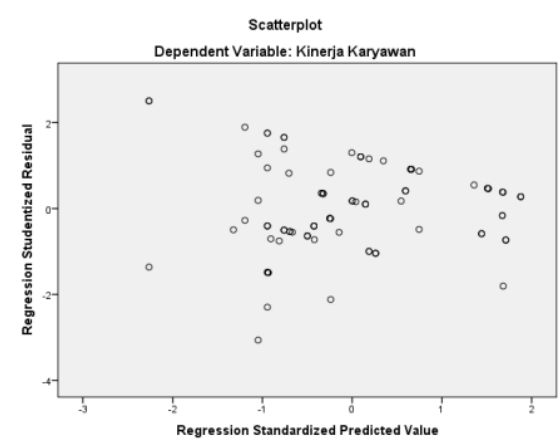

Sumber: Hasil olah data (2020)

\section{Gambar 3. HASIL UJI HETEROSKEDASTISITAS}

\section{Uji Autokorelasi}

Hasil uji autokorelasi menjelaskan nilai durbin-watson (d) memiliki angka 1.936. Nilai tersebut disinkronkan dengan nilai pada tabel durbin watson dengan jumlah sampel (n)=100 dan jumlah variabel independen $2(\mathrm{k}=2)$, maka dalam tabel durbin watson didapatkan angka batas atas (dU) 1,72. Berdasarkan pada ketentuan kedua yang mana angka $\mathrm{d}=1.936$ lebih besar dari angka $\mathrm{dU}=1,72$ dan kurang dari 4-1,72 (4-dU) = 2,28 atau 1,72<1.936<2,28 (Priyatno, 2010), maka dinyatakan (Ho) diterima, bisa diartikan tidak terjadi autokorelasi dan memenuhi asumsi autokorelasi.

\section{UJI T}

Berdasarkan analisi uji $t$, memperoleh nilai t hitung variabel lingkungan kerja memiliki angka 2,001 yang disinkronkan dengan nilai $\mathrm{t}$ tabel yaitu didapatkan angka 1,660 , hasilnya adalah $t$-hitung $>t$ tabel. Kemudian, nilai sig. variabel lingkungan kerja adalah 0,048 yang memiliki angka lebih kecil dari 0,05 . Merujuk pada tabel 2 , berarti bahwa Ha diterima dan Ho ditolak $\left(\beta_{1} \neq 0\right)$, artinya secara parsial lingkungan kerja berpengaruh terhadap kinerja karyawan.

Selanjutnya pada tabel 2, komitmen organisasi memperoleh nilai t hitung sejumlah 2,166 yang kemudian disinkronkan dengan $t$-tabel didapatkan angka 1,660, hasilnya adalah t hitung lebih besar daripada $t$-tabel ( $t$-hitung $>t$-tabel) (Sugiyono, 2011). Kemudian, nilai sig. komitmen organisasi adalah 
sebesar 0,033 yang memiliki angka lebih kecil dari 0,05 . Sehingga, Ha diterima dan Ho ditolak $\left(\beta_{2} \neq\right.$ 0 ), hal tersebut berarti secara parsial komitmen organisasi berpengaruh terhadap kinerja karyawan.

Tabel 2.

HASIL UJI T

\begin{tabular}{llrrrr}
\hline & & \multicolumn{4}{c}{ Unstandardized Coefficients } \\
Model & $\mathbf{B}$ & Std. Error & \multicolumn{1}{c}{ t } & Sig. \\
\hline 1 & (Constant) & 18.328 & 3.503 & 5.232 & .000 \\
& Lingkungan Kerja & .181 & .091 & 2.001 & .048 \\
& Komitmen Organisasi & .162 & .075 & 2.166 & .033 \\
\hline
\end{tabular}

Sumber: Hasil olah data (2020)

\section{Uji F}

Analisis uji $\mathrm{F}$ menunjukkan nilai $\mathrm{F}$ hitung variabel lingkungan kerja dan komitmen organisasi yang memiliki angka 13,427 dan disinronkan dengan nilai F-tabel yaitu 3,090, hasilnya adalah F-hitung > F-tabel (Sugiyono, 2011). Kemudian, nilai sig. variabel lingkungan kerja dan komitmen organisasi bernilai 0,000, lebih kecil dari 0,05. Merujuk pada tabel 3, bisa diartikan Ha diterima dan Ho ditolak $\left(\beta_{1}: \beta_{2} \neq 0\right)$, yang berarti bahwa secara simultan variabel lingkungan kerja dan komitmen organisasi berpengaruh terhadap kinerja karyawan.

Tabel 3.

\section{HASIL UJI F}

\begin{tabular}{|c|c|c|c|c|}
\hline Model & Df & Mean Square & $\mathbf{F}$ & Sig. \\
\hline 1 Regression & 2 & 187.592 & 13.427 & $.000^{\mathrm{b}}$ \\
\hline Residual & 97 & 13.972 & & \\
\hline Total & 99 & & & \\
\hline
\end{tabular}

Sumber: Hasil olah data (2020)

\section{Pengaruh Lingkungan Kerja terhadap Kinerja Karyawan}

Hasil pengujian menjelaskan bahwa lingkungan kerja memiliki pengaruh positif signifikan secara parsial terhadap kinerja karyawan PT. Sinar Niaga Sejahtera Sidoarjo. Hasil tersebut memiliki arti apabila semakin kondusif lingkungan kerja yang terbentuk, maka akan meningkatkan kinerja karyawan PT. Sinar Niaga Sejahtera Sidoarjo.

Hasil tersebut selaras dengan analisis studi yang dihasilkan oleh Farantoro \& Nasution (2013) dan menjelaskan bahwa lingkungan kerja secara parsial memiliki dampak atau kontribusi positif dan signifikan atas meningkatnya kinerja pegawai bidang konstruksi dan bangunan Dinas PU Provinsi Bengkulu. Dalam analisisnya juga menjelaskan kinerja pegawai telah dapat dikatakan baik, sehingga menggambarkan bahwa pegawai memiliki sikap dan hasil kerja yang telah baik. Hal ini didukung oleh adanya lingkungan kerja yang harmonis dan komunikatif. Selanjutnya, sesuai pula dengan hasil studi yang dihasilkan oleh Triwibowo \& Zamora (2016) yang menjelaskan lingkungan kerja berpengaruh positif dan signifikan terhadap kinerja karyawan kantor pelayanan Grapari Telkomsel Cabang Batam. Analisis yang dilakukan menemukan fakta pada dasarnya kinerja karyawan sudah baik, sebab didukung oleh lingkungan kerja yang memadai. Oleh karena itu, apabila lingkungan kerja dalam kondisi senang, maka tingkat lelah, kebosanan dan kejenuhan dapat ditekan serta kualitas kerja akan dapat dimaksimalkan. PT. Sinar Niaga Sejahtera Sidoarjo memiliki dampak yang sama dengan karyawan di bidang konstruksi dan bangunan karena dihuni oleh sebagian karyawan laki-laki dan bekerja di luar kantor (lapangan). Namun, sedikit berbeda dengan karyawan kantor pelayanan Grapari telkomsel yang berada di bidang industri yang berbeda dan kemungkinan dihuni oleh lebih banyak karyawan perempuan karena berbasis pelayanan yang cenderung memakai jasa perempuan dalam melayani konsumennya. Meskipun demikian, lingkungan kerja yang kondusif dan komitmen 
Putri Amalia Rulysca. Determinasi Lingkungan Kerja dan Komitmen Organisasi terhadap Kinerja Karyawan PT. Sinar Niaga Sejahtera Sidoarjo

organisasi yang tinggi dari seorang karyawan sama-sama diperlukan untuk meningkatkan kinerja mereka.

Berdasarkan temuan jawaban responden pada lingkungan kerja, banyak karyawan yang menjawab setuju dengan kondisi lingkungan kerja mereka. Hal tersebut mencerminkan sebenarnya karyawan merasa lingkungan kerja mereka dalam kondisi baik. Selain itu, pihak PT. Sinar Niaga Sejahtera Sidoarjo perlu memperhatikan beberapa poin yaitu menyediakan tempat istirahat yang memadai. Oleh karena itu, yang dapat menjadi pertimbangan adalah perusahaan menyediakan tempat khusus di dalam perusahaan untuk karyawan beristirahat di sela-sela kerjanya, sehingga kinerja mereka tidak terhambat.

\section{Pengaruh Komitmen Organisasi terhadap Kinerja Karyawan}

Hasil pengujian menjelaskan bahwa komitmen organisasi berpengaruh positif signifikan secara parsial terhadap kinerja karyawan PT. Sinar Niaga Sejahtera Sidoarjo. Hasil tersebut berarti apabila komitmen organisasional dalam diri karyawan semakin besar, maka akan meningkatkan kinerja karyawan PT. Sinar Niaga Sejahtera Sidoarjo.

Hasil tersebut sesuai dengan studi Farantoro \& Nasution (2013) yang menjelaskan komitmen organisasi secara parsial memiliki dampak atau kontribusi positif dan signifikan atas meningkatnya kinerja pegawai. Studi tersebut menguraikan kinerja pegawai telah dapat dikatakan baik, sehingga menggambarkan pegawai memiliki sikap dan hasil kerja yang telah baik. Hal ini dikarenakan mereka telah memiliki rasa komitmen yang besar untuk tetap bekerja di dalam institusi/organisasi. Begitu pula dengan studi Triwibowo \& Zamora (2016) yang menjelaskan komitmen organisasi berpengaruh positif dan signifikan terhadap kinerja karyawan. Studi tersebut menemukan fakta bahwa pada dasarnya kinerja karyawan sudah baik, sebab memiliki komitmen yang tinggi untuk dapat memajukan organisasi. Maka dari itu, pentingnya komitmen organisasi karena menunjukkan kesetiaan seorang karyawan kepada organisasi dan keinginan dari karyawan tersebut untuk mencapai tujuan organisasi secara maksimal.

Berdasarkan temuan jawaban responden pada komitmen organisasi, banyak karyawan yang menjawab setuju dengan komitmen organisasi mereka. Hal ini mencerminkan bahwa karyawan merasa komitmen mereka terhadap organisasi dalam kondisi baik. Selain itu, pihak PT. Sinar Niaga Sejahtera Sidoarjo perlu mengenal karyawannya lebih dalam, karena hasil jawaban menunjukkan beberapa karyawan belum merasa memiliki organisasi sepenuhnya, ada kecenderungan karyawan suatu saat akan meninggalkan organisasi. Oleh karena itu, yang dapat menjadi pertimbangan adalah memotivasi karyawannya dengan pendekatan individu maupun dengan pemberian penghargaan yang setimpal atas hasil kerja mereka, sehingga kemungkinan mereka keluar dari organisasi menjadi kecil. Hal ini dapat menjadi bukti bahwa banyaknya pekerja/ karyawan yang dalam masa kerja kurang dari 5 tahun.

\section{Pengaruh Lingkungan Kerja dan Komitmen Organisasi terhadap Kinerja Karyawan}

Hasil pengujian menjelaskan lingkungan kerja dan komitmen organisasi secara bersama-sama atau simultan memiliki dampak atau kontribusi positif signifikan atas meningkatnya kinerja karyawan PT. Sinar Niaga Sejahtera Sidoarjo. Hal itu bisa diartikan apabila lingkungan kerja yang terbentuk semakin kondusif dan komitmen berorganisasi yang berada pada diri karyawan terbentuk secara baik, maka dimungkinkan berkontribusi atas peningkatan kinerja karyawan PT. Sinar Niaga Sejahtera Sidoarjo.

Analisis tersebut sesuai dengan studi Farantoro \& Nasution (2013) yang menjelaskan motivasi kerja, komitmen organisasi, lingkungan kerja memiliki dampak atau berkontribusi positif dan signifikan secara simultan atas meningkatnya kinerja pegawai. Kinerja pegawai telah dapat dikatakan baik, sehingga menggambarkan pegawai memiliki sikap dan hasil kerja yang telah baik. Hal ini dikarenakan mereka telah memiliki motivasi kerja yang besar dan mempunyai komitmen kuat untuk senantiasa tinggal dalam organisasi, sebab adanya lingkungan kerja yang harmonis dan komunikatif. Begitu pula dengan studi Triwibowo \& Zamora (2016) yang menghasilkan lingkungan kerja, disiplin kerja dan komitmen organisasi secara simultan memiliki dampak atau berkontribusi positif dan 
signifikan atas meningkatnya kinerja karyawan. Dalam uraian studinya menemukan fakta pada dasarnya kinerja karyawan sudah baik, sebab adanya kontribusi lingkungan kerja yang memadai, serta terbentuknya komitmen dalam diri yang besar dalam rangka memajukan institusi/organisasi. Namun, perlu adanya peningkatan disiplin kerja karyawan, sebab beberapa karyawan menunjukkan kurang efisien dalam bekerja.

Berdasarkan temuan jawaban responden pada kinerja karyawan, banyak karyawan yang menjawab setuju bahkan sangat setuju dengan pernyataan kinerja mereka. Hal ini mencerminkan bahwa hasil kerja karyawan dalam bekerja dalam kondisi baik. Selain itu, pihak PT. Sinar Niaga Sejahtera Sidoarjo perlu memperhatikan tanggung jawab dan sikap karyawannya, karena ada beberapa karyawan yang bertindak di luar prosedur dan belum mengikuti arahan pihak manajemen. Oleh karena itu, yang dapat menjadi pertimbangan adalah perlunya pengawasan yang lebih rinci terhadap proses kerja karyawannya, sehingga kemungkinan mereka bertindak di luar prosedur dan tidak mengikuti arahan dari pihak manajemen semakin kecil serta kinerja karyawan yang dibutuhkan oleh instansi/organisasi akan cenderung terpenuhi.

\section{KESIMPULAN}

Mengacu pada penjelasan analisis, bisa dijelaskan bahwa lingkungan kerja dan komitmen organisasi memiliki dampak atau berkontribusi positif signifikan atas meningkatnya kinerja karyawan PT. Sinar Niaga Sejahtera Sidoarjo, baik secara parsial maupun secara simultan. Hal tersebut dibuktikan dengan hasil analisis uji t dan uji F yang menggambarkan hubungan positif dan signifikan.

Saran yang dapat diberikan terkait dengan kondisi yang ada yaitu pihak manajemen PT. Sinar Niaga Sejahtera Sidoarjo perlu mempertahankan kondisi lingkungan kerja saat ini dan komitmen organisasi yang telah terbentuk pada diri para karyawan, karena mayoritas dari mereka menjawab setuju yang merupakan respon baik terhadap kondisi perusahaan. Selain itu, hal yang perlu ditingkatkan yaitu perlunya menyediakan kantin atau ruang istirahat karyawan, perlunya memotivasi karyawannya dengan pendekatan individu maupun dengan pemberian penghargaan yang setimpal atas hasil kerja mereka agar kemungkinan mereka keluar dari organisasi menjadi kecil serta perlunya pengawasan yang lebih rinci terhadap proses kerja karyawannya agar kemungkinan mereka bertindak di luar prosedur dan tidak mengikuti arahan dari pihak manajemen semakin kecil. Studi selanjutnya bisa dapat melibatkan faktor-faktor yang lain misalnya kompensasi dan motivasi kerja karyawan.

\section{DAFTAR PUSTAKA}

Abidin, M. I. Z., Pangtuluran, Y., \& Maria, S. (2016). Pengaruh Kepuasan Kerja, Lingkungan Kerja dan Efikasi Diri Terhadap Komitmen Organisasi di Rumah Sakit SMC Samarinda. AKUNTABEL: Jurnal Ekonomi Dan Keuangan, 3(1), 1-10.

Ahmad, N., Iqbal, N., Javed, K., \& Hamad, N. (2014). Impact of Organizational Commitment and Employee Performance on the Employee Satisfaction. International Journal of Learning, Teaching and Educational Research, 1(1), 84-92.

Aprillia, V. D. S. (2015). Pengaruh Lingkungan Kerja, Disiplin Kerja dan Komitmen Organisasi Terhadap Kinerja Karyawan PT. Indomulti Plasindo di Kota Semarang. Jurnal Ekonomi Dan Bisnis, 1(1), 1-12.

Baraba, R. (2013). Pengaruh Lingkungan Kerja dan Komitmen Organisasi Terhadap Kepuasan Kerja Perawat (Studi pada RSU PKU Muhammadiyah Tunas Medika Purworejo. JBTI, IV(1), 61-71.

Dewi, I. S. (2015). Pengaruh Kepuasan dan Lingkungan Kerja Terhadap Kinerja Karyawan dengan Perilaku Kewargaan Organisasional Sebagai Variabel Intervening (Studi pada Karyawan PT Indonesian Knitting Factory Semarang). Skripsi Fakultas Ekonomi Semarang: Universitas 
Putri Amalia Rulysca. Determinasi Lingkungan Kerja dan Komitmen Organisasi terhadap Kinerja Karyawan PT. Sinar Niaga Sejahtera Sidoarjo

Negeri Semarang

Dharmanegara, I. B. A., Sitiari, N. W., \& Adelina, M. E. (2016). The Impact of Organizational Commitment, Motivation and Job Satisfaction on Civil Servant Job Performance in State Plantation Denpasar. Journal of Business and Management (IOSR-JBM), 18(2), 41-50.

Farantoro, W. A., \& Nasution. (2013). Pengaruh Motivasi Kerja, Komitmen Organisasi dan Lingkungan Kerja Terhadap Kinerja Pegawai (Studi pada Balai Pengujian Bidang Konstruksi dan Bangunan Dinas PU Provinsi Bengkulu). The Manager Review (Jurnal Ilmiah Manajemen), 15(15), 765-775.

Hakim, A. (2015). Effect of Organizational Culture, Organizational Commitment to Performance: Study in Hospital of District South Konawe of Southeast Sulawesi. The International Journal of Engineering and Science (IJES), 4(5), 33-41.

Handaru, A. W., Utomo, T., \& Sudiarditha, I. K. R. (2013). Pengaruh Lingkungan Kerja, Kompensasi dan Komitmen Organisasi Terhadap Kepuasan Kerja Karyawan di RS X. Jurnal Riset Manajemen Sains Indonesia (JRMSI), 4(1), 116-135.

Jonathan, H., Darroux, C., \& Massele, J. (2013). Perceived Job Satisfaction and Its Impact on Organizational Commitment: An Empirical Study of Public Secondary School Teachers in Dodoma, Tanzania. IOSR Journal of Business and Management (IOSR-JBM), 13(3), 41-52.

Maryanto. (2016). Pengaruh Kepemimpinan, Lingkungan Kerja, Organizational Citizenship Behavior (OCB) dan Komitmen Organisasi Terhadap Kinerja Pegawai di Kantor Kecamatan Gondangrejo Kabupaten Karanganyar. Ji@P, 3(2), 159-168.

Nazwirman. (2019). Analysis of Employee Performance: A Case Study in Port Corporation. Organization and Management Journal, 15(1), 24-35.

Pitaloka, E., \& Sofia, I. P. (2014). The Affect of Work Environment, Job Satisfaction, Organization Commitment on OCB of Internal Auditors. International Journal of Business, Economics and Law, 5(2), 10-18.

Priyatno, D. (2010). Teknik Mudah dan Cepat Melakukan Analisis Data Penelitian dengan SPSS dan Tanya Jawab Ujian Pendadaran. Gava Media.

Qatmeemalmarhoon, A. B. A. S., Mohdnoor, K. Bin, Abdalla, M. A. D., \& Musbah, A. R. (2017). Effect of Motivation on Employees' Performance and Employees' Commitment. International Journal of Management and Applied Science, 3(9), 39-43.

Rivai, V., \& Basri. (2005). Performance Appraisal: Sistem yang Tepat untuk Menilai Kinerja Pegawai dan Meningkatkan Daya Saing Perusahaan. Jakarta: PT. RajaGrafindo Persada.

Samson, G. N., Waiganjo, M., \& Koima, J. (2015). Effect of Workplace Environment on the Performance of Commercial Banks Employees in Nakuru Town. International Journal of Managerial Studies and Research (IJMSR), 3(12), 76-89.

Sari, D. (2015). Pengaruh Kepuasan Kerja dan Komitmen Organisasi Terhadap Kinerja Karyawan Pada PT.PUSKOPKAR Riau Pekanbaru. JOM FEKON, 2, 1-14.

Sugiyono. (2011). Statistik untuk Penelitian (Cetakan 19). CV. Alfabeta.

Triwibowo, A., \& Zamora, R. (2016). Pengaruh Lingkungan Kerja, Disiplin Kerja dan Komitmen Organisasi Terhadap Kinerja Karyawan pada Kantor Pelayanan Grapari Telkomsel Cabang 
Batam. Jurnal EQUILIBIRIA, 3(2), 1-22.

Widodo, D. S. (2014). Influence of Leadership and Work Environment to Job Satisfaction and Impact to Employee Performance (Study on Industrial Manufacture in West Java). Journal of Economics and Sustainable Development, 5(26), 62-66.

Yamin, S., \& Kurniawan, H. (2014). SPSS Complete: Teknik Analisis Statistik Terlengkap dengan Software SPSS (Edisi 2). Jakarta: Penerbit Salemba Infotek. 